\title{
Effect of Integrated Weed Management and Nitrogen Levels on Weed Infestation and NPK Depletion by Weeds in Onion
}

\author{
Pushpa Ujjainiya ${ }^{*}$, M. R. Choudhary ${ }^{1}$, M. L. Jakhar ${ }^{2}$ and O. P. Garhwal ${ }^{1}$ \\ ${ }^{1}$ Department of Horticulture, SKN Agriculture University, Jobner, India \\ ${ }^{2}$ Department of PBG, SKN Agriculture University, Jobner, India \\ *Corresponding author
}

A B S T R A C T

\begin{tabular}{l} 
K e y w o r d s \\
$\begin{array}{l}\text { Pendimethalin, } \\
\text { oxyfluorfen, onion, } \\
\text { weed infestation, } \\
\text { weed depletion, } \\
\text { nitrogen }\end{array}$ \\
\hline Article Info \\
\hline $\begin{array}{l}\text { Accepted: } \\
\text { 05 February } 2020 \\
\text { Available Online: } \\
\text { 10 March } 2020\end{array}$ \\
\hline
\end{tabular}

Field experiments were carried out at Horticulture Farm, Department of Horticulture, SKN Agriculture University, Jobner during 2016-17 and 2017-18 rabi seasons in the loamysand soil to study the effect of weed management and plant nutrition practices on weed infestation and NPK depletion by weeds in onion (Allium cepa L.). Weed management practices included seven weed control treatments. The crop was fertilized with four levels of $\mathrm{N}$ under the recommended rate of $\mathrm{P}, \mathrm{K}$, and $\mathrm{S}$. The results indicated that weed management and $\mathrm{N}$ levels had a significant effect on weed infestation and NPK depletion by weeds. Application of pendimethalin $(\mathrm{PP})+$ oxadiargyl at 40 DAT $\left(\mathrm{W}_{3}\right)$ or application of pendimethalin $(\mathrm{PP})+1 \mathrm{HW}$ at $40 \mathrm{DAT}$ or twice $\mathrm{HW}$ at 20 and 40 DAT alongwith $100 \mathrm{~kg} \mathrm{~N} / \mathrm{ha}$ were found the equally effective treatments to reduce weed infestation and NPK depletion by weeds.

\section{Introduction}

Onion (Allium cepa L.) is one of the most important bulbous vegetablecrop over the world belonging to family Alliaceae. It is considered to be the second most important vegetable crop grown in the world after tomato. This crop is usually grown in light soils with low organic matter. The importance of onion is rising from its high nutritional value for human. It promotes appetite and useful against malaria, night blindness which also lowers blood pressure (Perane, 2001).

Onion has very poor competitive ability with weeds at all growing season due to inherent characteristics shortest plant, non-branching, slow growing initial stage and shallow root system. Yield losses in onion due to the weeds have been reported to the extent of 10 to 70 per cents (Phogat et al., 1989).In onion field Chenopodium album L., Chenopodium 
murale, Amaranthus viridis L., Cyperusrotundus L., Cynodondactylon L. were the major dominant weeds which could be minimized by the use of herbicides as one of the method of weed control.

Though hand weeding is a common practice in India, it is laborious, expensive and time consuming. A loss due to weeds mainly depends upon their intensity in the field as well as type of weed flora. In onion transplanting of seedlings can be followed by use of pre or post emergence herbicides alone or combination to overcome of weed problem in field.

Pendimethalin at $1 \mathrm{~kg} / \mathrm{ha}$ alone or combination with one hand weeding or oxyflurofen at $0.125 \mathrm{~kg} / \mathrm{ha}+$ one hand weeding and different combinations of hand weeding with application of pendimethalin (pre-planting) and oxyfluorfen (post-emergence) recorded significantly reduce in weight of weeds and higher weed control efficiency (Patel et al., 2011).

Onion crop requires higher levels of $\mathrm{N}$ fertilizer to get good vegetative growth and maximum bulb yield as well as, its need to develop the most effective and economical weed control. Increase level of $n$ fertilizer application caused increase total biomass of weeds Qasem, 2006). The objective of this investigation was to study the effect of different levels of $(\mathrm{N})$ fertilizers, some weed control treatments and their combined interactions on weed infestation and NPK depletion by weeds in onion field.

\section{Materials and Methods}

Field experiment was conducted on loamy sand soil at Horticulture Farm, Department of Horticulture, SKN Agriculture University, Jobnerlocated near Jaipur in Rajasthan (India) during 2016-17 and 2017-18 rabi seasons.
The soil having 0.21 per cent organic carbon and low in available nitrogen $\left(128.60 \mathrm{~kg} \mathrm{ha}^{-1}\right)$ and slightly alkaline in reaction ( $\mathrm{pH}$ 8.2). This experiment was conducted under split-plot design having three replications. There were seven weed management treatments which assigned to main plots, viz. $\mathrm{W}_{0}$ : weedy check (control); $\mathrm{W}_{1}$ : one hand weeding (HW) at 20 DAT; $\mathrm{W}_{2}$ : two HW at 20 and $40 \mathrm{DAT}^{\mathrm{D}} \mathrm{W}_{3}$ : pre-plant application (PP) of pendimethalin @ $1.0 \mathrm{~kg}$ a.i. ha ${ }^{-1}$ followed by oxadiargyl @ 0.09 $\mathrm{kg}$ a.i. ha ${ }^{-1}$ at $40 \mathrm{DAT} ; \mathrm{W}_{4}$ : pendimethalin (PP) @ $1.0 \mathrm{~kg}$ a.i. ha ${ }^{-1}$ followed by $1 \mathrm{HW}$ at 40 DAT; W 5 : oxyflourfen (PP) @ $0.125 \mathrm{~kg}$ a.i. ha $^{-1}$ followed by post plant spray of oxyflourfen@0.125 kg a.i. ha ${ }^{-1}$ at 20 DAT andW $_{6}$ : oxyflourfen (PP) @ $0.125 \mathrm{~kg} a . i . \mathrm{ha}^{-1}$ followed by $1 \mathrm{HW}$ at 40 DAT and four nitrogen doses which assigned to subplots, viz. $\mathrm{N}_{0}$ : control, $\mathrm{N}_{1}: 50 \mathrm{~kg} \mathrm{ha}^{-1}, \mathrm{~N}_{2}: 100 \mathrm{~kg} \mathrm{ha}^{-}$ ${ }^{1}$ and $\mathrm{N}_{3}: 150 \mathrm{~kg} \mathrm{ha}^{-1}$.

The experimental field was brought to fine tilth by repeated ploughing and harrowing. Application of well decomposed FYM (20 t $\mathrm{ha}^{-1}$ ) and recommended dose of fertilizers (50:150:50 kg PKS / ha) were incorporated in the soil. The experimental plots of size $1.5 \mathrm{~m} \mathrm{x}$ $1.5 \mathrm{~m}$ and the seedlings of variety RO- 252 were transplanted from nursery in mid of December month by keeping a distance of 15 $\mathrm{cm}$ from row to row and $10 \mathrm{~cm}$ from plant to plant. Plant protection practices were undertaken as per the package of practice. The observations were recorded on weed infestation and NPK depletion by weeds.

\section{Weed infestation (\%)}

Weed infestation of every weed control treatment was calculated by using the following formula:

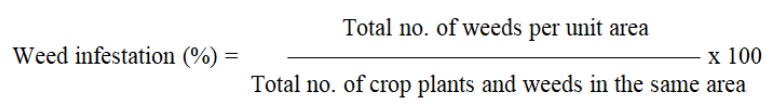




\section{Results and Discussion}

\section{Weed infestation $(\%)$}

Weed management treatments differed widely with respect to weed infestation in onion at various stages of crop growth (Table-1). The lowest weed infestation of $21.46,37.52,59.20$ and 66.72 per cent at 30,60 and 90 DAT and at harvest stages, respectively were recorded in treatment Two HW at 20 and 40 DAT $\left(\mathrm{W}_{2}\right)$.

Application of pendimethalin (PP) $+1 \mathrm{HW}$ at 40 DAT $\left(\mathrm{W}_{4}\right)$ and application of pendimethalin (PP) + oxadiargyl at 40 DAT $\left(\mathrm{W}_{3}\right)$ reduced the weed infestation by margin of 61.72 and 62.63 per cent at 90 DAT and 70.34 and 71.04 per cent at harvest stages, respectively and proved as the next better treatments, being statistically at par to treatment $\mathrm{W}_{2}$ at $90 \mathrm{DAT}$ and at harvest stage.

However, application of different doses of nitrogen did not bring significant changes in weed infestation per centage at any stage of crop growth in individual years as well as in pooled mean (Table 1).

Twice HW treatment controlled the second flush of weeds that emerged at later growth stages and thus provided the complete weed free environment throughout season. Earlier workers like Verma and Singh (1997) and Jayakumar and Bharati (2003) also obtained very good results with hand weeding and herbicides in reducing the weed population and increasing the yield of onion crop.

The inhibitory effect of herbicides like oxadiargyl and pendimethalin might have been responsible for reducing the population and intensity of weeds in treated plots. Vishnu et al., (2015) and Chattopadhyay et al., (2016) are in close harmony with the result of the present investigation.

\section{Nutrient (NPK) depletion by weeds (kg/ha)}

All the weed management treatments caused significant reduction in $\mathrm{N}, \mathrm{P}$ and $\mathrm{K}$ depletion in comparison to weedy check during individual years and in pooled mean (Table2).

Pooled analysis of data showed that application of pendimethalin (PP) + oxadiargyl at 40 DAT $\left(\mathrm{W}_{3}\right)$ recorded the lowest depletion of $\mathrm{N}, \mathrm{P}$ and $\mathrm{K}$ under weedy check. Application of pendimethalin $(\mathrm{PP})+1$ HW at 40 DAT and twice HW at 20 and 40 DAT were found the next better and equally effective treatments to $\mathrm{W}_{3}$ in reducing NPK depletion by weeds. It is also clear from the data (table 2) that significantly lower depletion of NPK by weeds was noted under control followed by $50 \mathrm{~kg} \mathrm{~N} / \mathrm{ha}$, being statistically at par with each other. However, the maximum depletion of NPK/ha by weeds was recorded under 150 and $100 \mathrm{~kg} \mathrm{~N} / \mathrm{ha}$ levels.

Interactive effect of weed management and $\mathrm{N}$ fertilization was also found significant in affecting NPK depletion by weeds at harvest stage (Table 3). Results revealed that the plots, wherein unrestricted growth of weeds $\left(\mathrm{W}_{0}\right)$ was allowed throughout the growing season, recorded the maximum mean depletion of 165.30, 26.69 and $144.70 \mathrm{~kg} \mathrm{~N}, \mathrm{P}$ and $\mathrm{k} / \mathrm{ha}$, respectively.

That was significantly higher than rest of the weed management treatments (Table 3). contrary to this, the minimum depletion of 12.08, 13.13 and $13.69 \mathrm{~kg} \mathrm{~N} / \mathrm{ha}, 1.82,1.97$ and $2.05 \mathrm{~kg} \mathrm{P} / \mathrm{ha}$ and $10.01,11.03$ and 11.68 $\mathrm{kg} \mathrm{K} / \mathrm{ha}$ was registered under pendimethalin (PP) fb oxadiargyl at 40 DAT $\left(\mathrm{W}_{3}\right)$, pendimethalin (PP) fb $1 \mathrm{HW}$ at $40 \mathrm{DAT}\left(\mathrm{W}_{4}\right)$ and two $\mathrm{HW}\left(\mathrm{W}_{2}\right)$ treatments, respectively. 
Table.1 Effect of weed management and nitrogen levels on weed infestation (\%) at different stages of crop

\begin{tabular}{|c|c|c|c|c|c|c|c|c|c|c|c|c|}
\hline \multirow[t]{2}{*}{ Treatments } & \multicolumn{3}{|c|}{30 DAT } & \multicolumn{3}{|c|}{60 DAT } & \multicolumn{3}{|c|}{90 DAT } & \multicolumn{3}{|c|}{ At harvest } \\
\hline & 2016-17 & 2017-18 & Pooled & 2016-17 & 2017-18 & Pooled & 2016-17 & 2017-18 & Pooled & 2016-17 & 2017-18 & Pooled \\
\hline \multicolumn{13}{|l|}{ Weed management - Main plots } \\
\hline $\begin{array}{l}\mathrm{W}_{0}-\text { Weedy check } \\
\text { (control) }\end{array}$ & 88.73 & 90.14 & 89.44 & 91.52 & 90.66 & 91.09 & 92.53 & 91.33 & 91.93 & 92.34 & 91.83 & 92.09 \\
\hline $\begin{array}{c}\mathrm{W}_{1} \text { - One hand weeding }(\mathrm{HW}) \\
\text { at } 20 \text { DAT }\end{array}$ & 22.68 & 27.27 & 24.98 & 75.18 & 72.14 & 73.66 & 83.48 & 81.56 & 82.52 & 87.59 & 86.54 & 87.07 \\
\hline $\begin{array}{c}\mathrm{W}_{2} \text { - Two hand weeding }(\mathrm{HW}) \\
\text { at } 20 \text { \& } 40 \mathrm{DAT}\end{array}$ & 20.53 & 22.38 & 21.46 & 29.99 & 45.05 & 37.52 & 58.85 & 59.54 & 59.20 & 68.8 & 66.63 & 67.72 \\
\hline 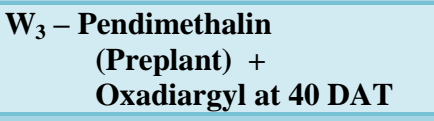 & 27.62 & 31.11 & 29.37 & 37.95 & 52 & 44.98 & 62.69 & 62.57 & 62.63 & 70.32 & 71.76 & 71.04 \\
\hline $\begin{array}{l}\mathrm{W}_{4}-\text { Pendimethalin } \\
\text { (Preplant) }+1 \mathrm{HW} \text { at } 40 \\
\text { DAT }\end{array}$ & 26.02 & 25.74 & 25.88 & 33.92 & 49.28 & 41.60 & 60.45 & 62.99 & 61.72 & 69.53 & 71.14 & 70.34 \\
\hline $\begin{array}{r}\mathrm{W}_{5} \text { - Oxyfluorfen (Preplant) }+ \\
\text { Oxyfluorfen at } 20 \text { DAT }\end{array}$ & 45.31 & 47.64 & 46.48 & 71.78 & 66.98 & 69.38 & 80.81 & 78.7 & 79.76 & 81.94 & 85.06 & 83.50 \\
\hline $\begin{array}{c}\text { W }_{6} \text { - Oxyfluorfen (Preplant) }+ \\
1 \text { HW at } 40 \text { DAT }\end{array}$ & 56.04 & 59.54 & 57.79 & 69.1 & 63.08 & 66.09 & 73.63 & 70.37 & 72.00 & 76.82 & 74.57 & 75.70 \\
\hline $\mathbf{S E m} \pm$ & 1.35 & 1.38 & 0.96 & 1.59 & 1.45 & 1.08 & 1.70 & 1.64 & 1.18 & 1.80 & 1.75 & 1.25 \\
\hline CD $(P=0.05)$ & 4.15 & 4.26 & 2.82 & 4.88 & 4.48 & 3.14 & 5.23 & 5.06 & 3.45 & 5.54 & 5.39 & 3.66 \\
\hline \multicolumn{13}{|l|}{$\begin{array}{l}\text { Nitrogen levels (kg/ha) - Sub } \\
\text { plots }\end{array}$} \\
\hline $\mathbf{N}_{0}-\mathbf{0}$ & 40.52 & 42.73 & 41.62 & 57.78 & 61.60 & 59.69 & 72.29 & 72.00 & 72.14 & 77.20 & 76.98 & 77.09 \\
\hline$N_{1}-50$ & 40.71 & 43.23 & 41.97 & 58.08 & 62.49 & 60.28 & 72.67 & 72.89 & 72.78 & 77.62 & 77.94 & 77.78 \\
\hline$N_{2}-100$ & 41.21 & 43.71 & 42.46 & 58.82 & 63.26 & 61.04 & 73.62 & 73.66 & 73.64 & 78.63 & 78.76 & 78.70 \\
\hline $\mathbf{N}_{3}-150$ & 41.52 & 43.95 & 42.73 & 59.30 & 63.62 & 61.46 & 74.24 & 74.06 & 74.15 & 79.31 & 79.20 & 79.25 \\
\hline $\mathrm{SEm} \pm$ & 0.44 & 0.46 & 0.32 & 0.67 & 0.70 & 0.49 & 0.83 & 0.83 & 0.59 & 0.90 & 0.89 & 0.63 \\
\hline $\mathrm{CD}(\mathrm{P}=0.05)$ & NS & NS & NS & NS & NS & NS & NS & NS & NS & NS & NS & NS \\
\hline
\end{tabular}


Table.2 Effect of weed management and nitrogen levels on NPK depletion $(\mathrm{kg} / \mathrm{ha})$ by weeds at harvest stage

\begin{tabular}{|c|c|c|c|c|c|c|c|c|c|}
\hline \multirow[t]{2}{*}{ Treatments } & \multicolumn{3}{|c|}{ N depletion (kg/ha) } & \multicolumn{3}{|c|}{ P depletion (kg/ha) } & \multicolumn{3}{|c|}{ K depletion (kg/ha) } \\
\hline & 2016-17 & 2017-18 & Pooled & 2016-17 & 2017-18 & Pooled & 2016-17 & 2017-18 & Pooled \\
\hline \multicolumn{10}{|l|}{ Weed management - Main plots } \\
\hline $\begin{array}{l}\mathrm{W}_{0} \text { - Weedy check } \\
\text { (control) }\end{array}$ & 163.67 & 166.93 & 165.30 & 26.10 & 27.28 & 26.69 & 145.39 & 144.00 & 144.70 \\
\hline $\begin{array}{l}W_{1} \text { - One hand weeding }(H W) \text { at } \\
20 \text { DAT }\end{array}$ & 47.56 & 51.04 & 49.30 & 7.28 & 7.68 & 7.48 & 41.82 & 43.32 & 42.57 \\
\hline $\begin{array}{l}\mathrm{W}_{2} \text { - Two hand weeding }(\mathrm{HW}) \text { at } \\
20 \& 40 \text { DAT }\end{array}$ & 12.65 & 14.73 & 13.69 & 1.90 & 2.20 & 2.05 & 10.78 & 12.57 & 11.68 \\
\hline $\begin{array}{c}\mathrm{W}_{3} \text { - Pendimethalin (Preplant) } \\
\text { + Oxadiargyl at } 40 \text { DAT }\end{array}$ & 11.58 & 12.58 & 12.08 & 1.73 & 1.90 & 1.82 & 9.6 & 10.41 & 10.01 \\
\hline $\begin{array}{c}\mathrm{W}_{4}-\text { Pendimethalin (Preplant) } \\
+1 \mathrm{HW} \text { at } 40 \text { DAT }\end{array}$ & 12.28 & 13.97 & 13.13 & 1.83 & 2.10 & 1.97 & 10.33 & 11.72 & 11.03 \\
\hline $\begin{array}{c}\text { W }_{5} \text { - Oxyfluorfen (Preplant) + } \\
\text { Oxyfluorfen at 20 DAT }\end{array}$ & 44.41 & 42.31 & 43.36 & 6.83 & 6.32 & 6.58 & 38.24 & 35.4 & 36.82 \\
\hline $\begin{array}{l}\text { W }_{6} \text { - Oxyfluorfen (Preplant) }+1 \\
\text { HW at } 40 \text { DAT }\end{array}$ & 20.60 & 23.46 & 22.03 & 3.10 & 3.52 & 3.31 & 17.40 & 19.64 & 18.52 \\
\hline SEm \pm & 1.35 & 1.12 & 0.90 & 0.21 & 0.18 & 0.14 & 1.19 & 0.96 & 0.79 \\
\hline $\mathrm{CD}(\mathbf{P}=\mathbf{0 . 0 5})$ & 4.16 & 3.44 & 2.63 & 0.66 & 0.55 & 0.42 & 3.68 & 2.95 & 2.30 \\
\hline \multicolumn{10}{|l|}{ Nitrogen levels (kg/ha) - Sub plots } \\
\hline $\mathbf{N}_{0}-\mathbf{0}$ & 40.12 & 41.90 & 41.01 & 6.26 & 6.57 & 6.42 & 35.09 & 35.72 & 35.41 \\
\hline $\mathbf{N}_{1}-\mathbf{5 0}$ & 41.18 & 43.35 & 42.27 & 6.58 & 6.70 & 6.64 & 36.56 & 36.79 & 36.67 \\
\hline$N_{2}-100$ & 47.52 & 49.53 & 48.53 & 7.41 & 7.77 & 7.59 & 41.74 & 42.41 & 42.08 \\
\hline$N_{3}-150$ & 48.90 & 50.94 & 49.92 & 7.62 & 7.99 & 7.81 & 42.93 & 43.40 & 43.16 \\
\hline SEm \pm & 0.72 & 0.79 & 0.53 & 0.11 & 0.13 & 0.09 & 0.63 & 0.68 & 0.46 \\
\hline CD $(\mathbf{P}=\mathbf{0 . 0 5})$ & 2.04 & 2.26 & 1.50 & 0.32 & 0.36 & 0.24 & 1.80 & 1.94 & 1.31 \\
\hline Interaction (W X N) & Sig. & Sig. & Sig. & Sig. & Sig. & Sig. & Sig. & Sig. & Sig. \\
\hline
\end{tabular}


Table.3 Interaction effect of weed management practices under nitrogen levels on $\mathrm{N}, \mathrm{P}$ and $\mathrm{K}$ depletion by weeds (kg/ha) at harvest stage (pooled mean of two years)

\begin{tabular}{|c|c|c|c|c|c|c|c|c|c|c|c|c|}
\hline \multirow{3}{*}{$\begin{array}{l}\text { Weed } \\
\text { manageme } \\
\text { nt-Main } \\
\text { plots }\end{array}$} & \multicolumn{12}{|c|}{ Nitrogen levels (kg/ha) - Sub plots } \\
\hline & \multicolumn{4}{|c|}{ N depletion (kg/ha) } & \multicolumn{4}{|c|}{ P depletion (kg/ha) } & \multicolumn{4}{|c|}{ K depletion (kg/ha) } \\
\hline & $\mathbf{N}_{\mathbf{0}}$ & $\mathbf{N}_{1}$ & $\mathbf{N}_{2}$ & $\mathbf{N}_{3}$ & $\mathbf{N}_{0}$ & $\mathbf{N}_{1}$ & $\mathbf{N}_{2}$ & $\mathbf{N}_{3}$ & $\mathbf{N}_{\mathbf{0}}$ & $\mathbf{N}_{1}$ & $\mathbf{N}_{2}$ & $\mathbf{N}_{3}$ \\
\hline $\mathrm{W}_{0}$ & $\begin{array}{c}148.8 \\
1\end{array}$ & 155.18 & $\begin{array}{c}176.0 \\
8\end{array}$ & $\begin{array}{c}181.1 \\
4\end{array}$ & 24.03 & 25.05 & 28.43 & 29.25 & 130.25 & 134.10 & 155.40 & $\begin{array}{c}159.0 \\
2\end{array}$ \\
\hline $\mathrm{W}_{1}$ & 44.38 & 46.27 & 52.52 & 54.03 & 6.73 & 7.02 & 7.97 & 8.20 & 38.32 & 39.96 & 45.35 & 46.65 \\
\hline $\mathrm{W}_{2}$ & 12.33 & 12.85 & 14.58 & 15.00 & 1.85 & 1.92 & 2.18 & 2.25 & 10.51 & 10.96 & 12.44 & 12.79 \\
\hline $\mathrm{W}_{3}$ & 10.88 & 11.34 & 12.87 & 13.24 & 1.63 & 1.70 & 1.93 & 1.99 & 9.01 & 9.39 & 10.66 & 10.96 \\
\hline $\mathrm{W}_{4}$ & 11.82 & 12.32 & 13.98 & 14.38 & 1.77 & 1.84 & 2.09 & 2.15 & 9.93 & 10.35 & 11.74 & 12.08 \\
\hline $\mathrm{W}_{5}$ & 39.03 & 40.71 & 46.19 & 47.51 & 5.92 & 6.17 & 7.00 & 7.20 & 33.14 & 34.57 & 39.22 & 40.35 \\
\hline $\mathrm{W}_{6}$ & 19.83 & 20.67 & 23.47 & 24.14 & 2.98 & 3.11 & 3.53 & 3.63 & 16.67 & 17.38 & 19.73 & 20.30 \\
\hline $\begin{array}{l}\text { For } \mathrm{N} \text { at same } \\
\text { level of } \mathrm{W}\end{array}$ & & & & & & & & & & & & \\
\hline $\mathrm{SEm} \pm$ & & 1.41 & & & & 0.23 & & & & 1.23 & & \\
\hline $\mathrm{CD}(\mathrm{P}=0.05)$ & & 3.97 & & & & 0.63 & & & & 3.45 & & \\
\hline $\begin{array}{l}\text { For } \mathrm{W} \text { at same } \\
\text { or different } \\
\text { levels of } \mathrm{N}\end{array}$ & & & & & & & & & & & & \\
\hline $\mathrm{SEm} \pm$ & & 1.52 & & & & 0.24 & & & & 1.32 & & \\
\hline $\mathrm{CD}(\mathrm{P}=0.05)$ & & 5.56 & & & & 0.89 & & & & 4.83 & & \\
\hline
\end{tabular}


These treatments were noted equally effective treatments in reducing nutrient depletion by weeds. These treatments reduced the $\mathrm{N}$ depletion by $92.69,92.06$ and 91.72 per cent, $\mathrm{P}$ depletion by 93.18, 92.62 and 92.32 per cent and $\mathrm{K}$ depletion by $93.08,92.38$ and 91.93 per cent than weedy check, respectively.

The drastic reduction in nutrient depletion by weeds under these superior treatments might be assigned to the corresponding reduction in dry matter accumulation of weeds by effective weed control and smothering effect of crop exerted on weed growth. Similar findings were also reported by Mehta (2000) in fennel and Yadav and Mehriya (2008) in cumin.

\section{References}

Chattopadhyay, N., Mahalanabish, S., Hore, J. K. and Maity, T. K. 2016. Effect of different herbicides on growth and yield of onion (Allium cepa L.). Journal of Crop and Weed, 12 (1): 112 - 115.

Jayakumar, R. and Bharati, C. 2003. Evaluation of fluchloralin, oxadiazon and pendimethalin residues in onion (Allium cepa L.). Indian Journal of Weed Science, 35: 291- 293.

Mehta, J. P. 2000. Weed management and nitrogen application in fennel (Foeniculum vulgare Mill). M.Sc. (Ag.) Thesis, Rajasthan Agricultural University, Bikaner.

Patel, T.U., Patel, C.L., Patel, D.D., Thanki,
J.D., Patel, P.S. and Ram, A.J. 2011. Effect of weed and fertilizer management on weed control and productivity of onion (Allium cepa L.). Indian J. Agronomy, 56(3): 267-272.

Perane, R.R. 2001. Studies on purple blotch of onion caused by Alternariya cepuleculi Rao with special reference to toxin production Ph.D. Thesis, Mahatma Phule Krishi Vidyapeeth, Rahuri, Ahmednagar (M.S.) INDIA.

Phogat, B.S., Bhan, V.M. and Singh, J. 1989. Efficacy of herbicides on weeds in Kharif onion. Indian J. Weed. Sci., 21 $(1 \& 2)$ : 78-79.

Qasem, J.R. 2006. Chemical weed control in seedbed sown onion (Allium cepa L.). Crop Protect, 25(6): 618-22.

Verma, S.K. and Singh, T. 1997. Effect of weed control measures and fertility on growth and productivity of rainy season onion (Allium cepa). Indian Journal of Agronomy, 42 (3): 540 -543.

Vishnu, V., Asodaria, K.B. and Suthar, A. 2015. Weed management in rabi onion (Allium cepa L.). Agriculture Science Digest, 35 (2): 130 - 133.

Yadav, R.S. and Mehriya, M.L. 2008. Effect of weed control methods on nutrient uptake and essential oil content of cumin (Cuminum cyminum L.). In: Abstracts of papers presented in National Workshop on "Recent Advance in seed spices" 6-7 February, 2008, ARS Mandore, Jodhpur. pp. 39.

\section{How to cite this article:}

Pushpa Ujjainiya, M. R. Choudhary, M. L. Jakhar and Garhwal. O. P. 2020. Effect of Integrated Weed Management and Nitrogen Levels on Weed Infestation and NPK Depletion by Weeds in Onion. Int.J.Curr.Microbiol.App.Sci. 9(03): 1300-1306. doi: https://doi.org/10.20546/ijcmas.2020.903.151 